\title{
A meta-analysis on growth, physiological, and biochemical responses of woody species to ground-level ozone highlights the role of plant functional types
}

\author{
Pin $\mathrm{Li}^{1,2} \mid$ Zhaozhong Feng ${ }^{1,2}$ (i) | Vicent Catalayud ${ }^{3} \mid$ Xiangyang Yuan ${ }^{1,2} \mid$ Yansen $\mathrm{Xu}^{1,2}$ | \\ Elena Paoletti ${ }^{1,4}$
}

\begin{abstract}
${ }^{1}$ State Key Laboratory of Urban and Regional Ecology, Research Center for Eco-

Environmental Sciences, Chinese Academy of Sciences, Shuangqing Road 18, Haidian

District, Beijing 100085, China

${ }^{2}$ College of Resources and Environment, University of Chinese Academy of Sciences, Beijing 100049, China

${ }^{3}$ Fundación CEAM, c/Charles R. Darwin 14, Parque Tecnológico, Paterna, Valencia 46980, Spain

${ }^{4}$ National Research Council, Via Madonna del Piano 10, Sesto Fiorentino 50019, Italy

Correspondence

Zhaozhong Feng, State Key Laboratory of Urban and Regional Ecology, Research Center for Eco-Environmental Sciences, Chinese Academy of Sciences, Beijing 100085, China. Email: fzz@rcees.ac.cn
\end{abstract}

\section{Funding information}

Key Research Program of Frontier Sciences, CAS, Grant/Award Number: QYZDB-SSWDQC019; the Hundred Talents Program, Chinese Academy of Sciences; Chinese Academy of Sciences President's International Fellowship Initiative (PIFI) for Senior Scientists, Grant/Award Number: 2016VBA057 and 2013T2Z0009; National Natural Science Foundation of China, Grant/Award Number: 31500396; CNR-CAS bilateral agreement 2017-2019; Ozone impacts on plant ecosystems in China and Italy

\begin{abstract}
The carbon-sink strength of temperate and boreal forests at midlatitudes of the northern hemisphere is decreased by ozone pollution, but knowledge on subtropical evergreen broadleaved forests is missing. Taking the dataset from Chinese studies covering temperate and subtropical regions, effects of elevated ozone concentration $\left(\left[\mathrm{O}_{3}\right]\right)$ on growth, biomass, and functional leaf traits of different types of woody plants were quantitatively evaluated by meta-analysis. Elevated mean $\left[\mathrm{O}_{3}\right]$ of $116 \mathrm{ppb}$ reduced total biomass of woody plants by $14 \%$ compared with control (mean $\left[\mathrm{O}_{3}\right]$ of $21 \mathrm{ppb}$ ). Temperate species from China were more sensitive to $\mathrm{O}_{3}$ than those from Europe and North America in terms of photosynthesis and transpiration. Significant reductions in chlorophyll content, chlorophyll fluorescence parameters, and ascorbate peroxidase induced significant injury to photosynthesis and growth (height and diameter). Importantly, subtropical species were significantly less sensitive to $\mathrm{O}_{3}$ than temperate ones, whereas deciduous broadleaf species were significantly more sensitive than evergreen broadleaf and needle-leaf species. These findings suggest that carbon-sink strength of Chinese forests is reduced by present and future $\left[\mathrm{O}_{3}\right]$ relative to control $(20-40 \mathrm{ppb})$. Given that (sub)-tropical evergreen broadleaved species dominate in Chinese forests, estimation of the global carbon-sink constraints due to $\left[\mathrm{O}_{3}\right]$ should be re-evaluated.
\end{abstract}

\section{KEYWORDS}

air pollution, China, growth, meta-analysis, $\mathrm{O}_{3}$, plant function type, subtropical, temperate, woody species

\section{1 | INTRODUCTION}

Ground-level ozone $\left(\mathrm{O}_{3}\right)$ is a secondary phytotoxic air pollutant, produced from photochemical reactions of $\mathrm{O}_{3}$ precursors mainly nitrogen oxides $\left(\mathrm{NO}_{x}\right)$ and volatile organic compounds of both natural and anthropogenic origins (Forster et al., 2007; International Panel on Climate Change, 2014). Rapid urbanization and industrialization without an effective air pollution control have driven substantial increases in $\mathrm{O}_{3}$ and its precursors over the past two decades in Asia, especially in China (Van der et al., 2008; Verstraeten et al., 2015). The $\mathrm{O}_{3}$ concentrations $\left(\left[\mathrm{O}_{3}\right]\right.$ ) over China have increased by about 7\% between 2005 and 2010 and are projected to further increase at a rate of $1 \%$ to $3 \%$ per year (Verstraeten et al., 2015). The yearly average of daily maximum $\left[\mathrm{O}_{3}\right]$ may reach $60 \mathrm{ppb}$ in megacities such as Beijing, Shanghai, and Guangzhou (Chen, Tang, \& Zhao, 2015; Feng, Paoletti, Bytnerowicz, \& Harmens, 2015). Such current background $\left[\mathrm{O}_{3}\right]$ is high enough to cause significant injury to plant and ecosystem 
health (Feng, Sun, Wan, Hu, \& Calatayud, 2014; Li, Calatayud, Gao, Uddling, \& Feng, 2016; Paoletti \& Manning, 2007).

Most concern on $\mathrm{O}_{3}$ impacts on Chinese plants has been traditionally focused on crops, because of the dramatically increased pressure on food supply in China (Feng et al., 2015; Wang, Manning, Feng, \& Zhu, 2007). However, China is one of the world's most forest-deficient countries, with $22 \%$ of forested land area compared with $30 \%$ worldwide (Fang et al., 2014). The Chinese government has launched several large-scale ecological rehabilitation and conservation programmes since the late 1990s (Figure S1), such as the Natural Forest Protection Program (Lü, Fu, Wei, Yu, \& Sun, 2011) and the Three-North Shelter Forest Program (Duan et al., 2011), thus carrying out the largest reforestation programme in the world (Ren et al., 2015). Natural and planted forests of China host a large variety of vascular plants and terrestrial vertebrate species, corresponding to $10 \%$ of the world's biodiversity (Liu \& Diamond, 2005). Protection of Chinese forests from environmental stressors such as $\mathrm{O}_{3}$ is thus an issue of rising interest. The first paper on $\mathrm{O}_{3}$ impacts on Chinese woody species was published in 2006 (He, Ruan, Chen, \& Lu, 2006). Since then, more than 60 experimental studies have been carried out in southern and northern China to investigate $\mathrm{O}_{3}$ effects on woody species native of China or largely cultivated in China-e.g., for ornamental and greening purposes-in terms of gas exchange, chlorophyll a fluorescence, antioxidant system, and growth (e.g., Feng \& Li, 2017; Feng et al., 2011; Gao, Catalayud, García-Breijo, Reig-Armiñana, \& Feng, 2016; He et al., 2007; Xu, He, Chen, Su, \& Huang, 2014; Yan et al., 2010).

China covers cold temperate, temperate, warm temperate, subtropical, and tropical climate zones from north to south (Fang et al., 2012). Such broad climatic gradient supports diverse forest types ranging from deciduous coniferous species in the north to evergreen broadleaved species in the south (Figure S1). These diverse forest types in China provide an ideal framework to expand our understanding of $\mathrm{O}_{3}$ impacts across plant functional types, especially for evergreen species and deciduous species. Tropical forest composition is dominated by evergreen broadleaf tree species (EBL), which are usually considered more $\mathrm{O}_{3}$ tolerant than deciduous broadleaved species (DBL; Calatayud, Marco, Cervero, Sanchez-Pena, \& Sanz, 2010; Li et al., 2016; Paoletti, 2006; Zhang, Feng, Wang, \& Niu, 2012). However, no synthetic comparison to quantify differences between $\mathrm{EBL}$ and $\mathrm{DBL}$ in response to $\mathrm{O}_{3}$ is available so far.

Two previous meta-analytic papers synthesized the knowledge about $\mathrm{O}_{3}$ impacts on tree biomass, growth, gas exchange, physiology, and biochemistry by using studies carried out in North America and Europe on angiosperms and gymnosperms from temperate and boreal climates (Wittig, Ainsworth, \& Long, 2007; Wittig, Ainsworth, Naidu, Karnosky, \& Long, 2009). Results indicated that elevated $\left[\mathrm{O}_{3}\right]$ reduced leaf photosynthetic $\mathrm{CO}_{2}$ uptake $(-11 \%)$, stomatal conductance (-13\%; Wittig et al., 2007), and total biomass (-17\%) compared with charcoal-filtered controls (Wittig et al., 2009); also, gymnosperms were significantly less sensitive than angiosperms to elevated $\left[\mathrm{O}_{3}\right]$ (Wittig et al., 2009). These two pioneering studies provided a summary understanding of $\mathrm{O}_{3}$ impacts on photosynthesis, biomass, and production of northern hemisphere temperate and boreal forests, but several points remain to be addressed. First, previous studies did not cover antioxidant parameters, which are critical to achieve an effective defence against $\mathrm{O}_{3}$ (Castagna \& Ranieri, 2009; Paoletti, Ranieri, \& Lauteri, 2008). Second, little is known about the response difference between plant functional types such as (sub)-tropical versus temperate species or EBL versus DBL species. Tropical forests are the richest biological communities on Earth and harbour a significant proportion of global biodiversity (Myers, Mittermeier, Mittermeier, Fonseca, \& Kent, 2000) and terrestrial carbon (van der Sleen et al., 2015). In the tropics, $\mathrm{O}_{3}$ pollution is recognized as a serious air quality issue (Allen, Sherwood, Norris, \& Zender, 2012), and the understanding of forests responses to $\mathrm{O}_{3}$ is largely imperfect (The Royal Society, 2008). Therefore, it is important to investigate the response of (sub)-tropical species to $\mathrm{O}_{3}$ and compare the responses of (sub)-tropical and temperate species based on measurements.

The objective of this paper was to quantitatively synthesize effects of $\mathrm{O}_{3}$ on woody species in China through meta-analytic techniques-with focus on growth, biomass, gas exchange, photosynthetic pigments, chlorophyll fluorescence, and antioxidant parameters-and compare the response to $\mathrm{O}_{3}$ between plant functional types. We addressed the following questions: (a) to what extent is the productivity of Chinese woody species reduced by current and future $\left[\mathrm{O}_{3}\right]$, and what are the underlying ecophysiological parameters for such decreases in productivity? (b) How are the responses to $\mathrm{O}_{3}$ dependent on plant functional type and bioclimatic zone? Finally, the impact of this improved knowledge on the potential carbon and water cycles at global level was discussed.

\section{2 | MATERIALS AND METHODS}

\section{1 | Database}

A database of effects of $\mathrm{O}_{3}$ on growth, biomass, physiology, and biochemistry of woody species was compiled by surveying the peer-reviewed literature with China National Knowledge Infrastructure (http://www.cnki.net/) and Web of Science (Thompson-ISI, Philadelphia, PA, USA, http://apps.webofknowledge.com) using "ozone," "O ${ }_{3}$," "forest," "tree," "woody," and "China" as keywords. As the very first paper was published in 2006, this search covered the period between January 2006 and April 2016 and identified 71 articles that reported elevated $\left[\mathrm{O}_{3}\right]$ effects on woody species in China. To avoid missing relevant references, the reference lists of any article identified by the keyword search were cross-checked. Articles and their measurements were excluded if (a) $\mathrm{O}_{3}$ fumigation was shorter than 7 days and therefore not representative of chronic exposure, (b) elevated $\left[\mathrm{O}_{3}\right]$ was lower than $30 \mathrm{ppb}$, (c) the data were previously or more completely reported in another article, and (d) the standard deviation could not be determined or there was no replication. After excluding articles based on these criteria, 46 articles including 61 woody species were used for this meta-analysis (Table S1). For each observation of variables, the mean value, the standard deviations, and the replication in the control and elevated $\left[\mathrm{O}_{3}\right]$ treatment were extracted and entered into the database together with the categorical information, including $\left[\mathrm{O}_{3}\right]$ and duration (Table S1). The values of each variable were taken directly from tables or text, when reported; data 
from the graphs were extracted using the GetData Graph Digitizer, version 2.26 (http://getdata-graph-digitizer.com/). We used the bioclimatic classification (Wu et al. 2010) and Flora of China (http://frps. eflora.cn/) to categorize the species into temperate or subtropical, evergreen or deciduous, and broadleaf or needle leaf (NDL). The dataset included 26 evergreen and 35 deciduous species, 31 subtropical ( 25 evergreen vs. 6 deciduous) and 30 temperate ( 1 evergreen vs. 29 deciduous) species, and 56 broadleaf (22 evergreen vs. 34 deciduous) and 5 NDL (4 evergreen vs. 1 deciduous) species (Table S1).

Meta-analytic methods require that individual observations are statistically independent. Parameter values were considered independent if they were made on different species or distinct genotypes within a species, $\left[\mathrm{O}_{3}\right]$, additional treatments, or if the measurements were made on different dates and different years in the same experiment. Within each article, measures of final biomass (total dry biomass, shoot dry biomass, and root dry biomass), root-to-shoot ratio, height, diameter, leaf size, nitrogen content on a mass basis of leaf, shoot and root, and leaf per mass area were recorded at the end of the experiment. If gas exchange measurements were made over the diurnal course, only values for light-saturating conditions were recorded in the database.

\section{2 | Sources of variation}

To explain the variation in the response of woody species to elevated $\left[\mathrm{O}_{3}\right]$, four categories were included as follows (Table S1): (a) plant type (subtropical vs. temperate, evergreen vs. deciduous, and needle leaf vs. broadleaf); (b) mean $\left[\mathrm{O}_{3}\right]$ over the entire experiment ( $<40,40-59,60-$ $89,90-119$, and $>120 \mathrm{ppb}$ ); (c) duration of $\mathrm{O}_{3}$ exposure (7-29, 30-59, $60-89,90-119,120-149,150-365$, and $\geq 365$ days), according to Wittig et al. (2007); and (d) additional treatments (no additional treatments, elevated concentration of atmospheric carbon dioxide ([ $\left.\left.\mathrm{CO}_{2}\right]\right)$, drought, or nitrogen addition). As all studies were carried out on potted plants in open top chambers (OTCs) with seedlings and saplings, it was not possible to categorize the rooting environment (potted vs. in the ground) or the exposure environment (closed chamber, OTC, and free air). Except in the case of drought treatments, all plants were manually irrigated to keep soil moisture uniform and close to soil field capacity. The duration of the daily exposure varied from 8 to $10 \mathrm{hr}$ and thus was not categorized. The mean $\left[\mathrm{O}_{3}\right]$ in the control and in the treatment was defined as the hourly average $\left[\mathrm{O}_{3}\right]$ of the entire exposure period.

\section{3 | Meta-analyses}

The meta-analysis was conducted using a meta-analytical software package (METAWIN 2.1.3.4, Sinauer Associates, Inc., Sunderland, MA, USA; Rosenberg et al. 2000). To estimate the treatment effect, the natural log of the response ratio $\left(r=\right.$ variable in elevated $\left[\mathrm{O}_{3}\right] /$ variable in control air) was used as the metric for analysis (Rosenberg et al. 2000), and the percentage change from the control was reported as $(r-1) \times 100 \%$ (Curtis \& Wang 1998; Feng et al. 2008; Wittig et al., 2009). Negative percentage changes indicate a decrease in the variable in response to elevated $\left[\mathrm{O}_{3}\right]$ treatment, whereas positive values indicate an increase. The variance of the effect size was calculated using resampling techniques after 9,999 iterations (Ainsworth et al.
2002; Feng et al. 2008). Confidence limits around the effect size were calculated using a bootstrap method (Rosenberg et al. 2000). Estimates of the effect size were assumed to be significant if the $95 \%$ confidence intervals (Cls) did not overlap 0 (Curtis \& Wang 1998).

Eight categorical variables were analysed (Table 1). Betweengroup heterogeneity $\left(Q_{B}\right)$ for each category was examined, and data were subdivided according to levels of those categorical variables with significant $Q_{B}$ (i.e., $p$ value < .05). If $95 \% \mathrm{Cl}$ did not overlap, means were significantly different from one another (Curtis \& Wang 1998; Ainsworth et al. 2002). Levels of each category were included in this analysis if there were at least 10 observations or more than 5 observations but originated from at least two independent papers, which follows previous meta-analyses on trees and crops (Feng et al. 2008; Wittig et al., 2009).

\section{I RESULTS}

\subsection{Overview on the database of $\mathrm{O}_{3}$ effects on woody species in China}

All 61 species were grown in pots and exposed in OTCs. The mean fumigated $\left[\mathrm{O}_{3}\right]$-as a mean calculated from hourly data over the entire experiment-ranged from 40 to $200 \mathrm{ppb}$, control $\left[\mathrm{O}_{3}\right]$ ranged from 20 to $45 \mathrm{ppb}$ (Figure 1), and the total duration of the experiments ranged from 15 to 240 days (Table S1). The studies that included elevated $\left[\mathrm{O}_{3}\right]$ in combination with additional treatments were with elevated $\left[\mathrm{CO}_{2}\right]$ (10 studies), with drought (4 studies), and with nitrogen addition ( 2 studies). Given that there were too few observations of the interaction of $\left[\mathrm{O}_{3}\right]$ with these additional treatments, and no significant interaction was evident across the studies (except for one variable, effective quantum yield of photosystem II [PSII] photochemistry, $\varphi$ PSII, in interaction with drought, $p=.0106$, Table 1), it could not be assessed how these climate change factors alter woody plant responses to $\left[\mathrm{O}_{3}\right]$.

\section{2 | Overall effects of elevated $\left[\mathrm{O}_{3}\right]$}

Across all studies, total biomass decreased by $14 \%$ at a mean $\left[\mathrm{O}_{3}\right]$ of $116 \mathrm{ppb}$ compared with the control (mean $\left[\mathrm{O}_{3}\right]$ of $21 \mathrm{ppb}$; Figure 1a). Similar decreases under similar $\left[\mathrm{O}_{3}\right](128 \mathrm{ppb})$ were found in root (13\%) and shoot biomass (8\%). Seedling height, diameter at base, leaf mass per area (LMA), and leaf size were also decreased by $7 \%, 7 \%$, $6 \%$, and $16 \%$ at $83-128 \mathrm{ppb}$, respectively. Elevated $\left[\mathrm{O}_{3}\right]$ (98-150 ppb) did not significantly affect crown breadth, the concentrations of leaf nitrogen $(\mathrm{N})$, shoot $\mathrm{N}$, root $\mathrm{N}$, and the root-toshoot ratio.

The reduction (28\%) in light-saturated $\mathrm{CO}_{2}$ assimilation rate $\left(A_{\text {sat }}\right)$ was similar to the reduction in stomatal conductance $\left(g_{\mathrm{s}}\right), 29 \%$, under similar $\left[\mathrm{O}_{3}\right]$ of 102 and $109 \mathrm{ppb}$ (Figure 1b). Ozone-induced decrease in chlorophyll $a(17 \%)$ and chlorophyll $b(20 \%)$ resulted in decreased total chlorophyll content (17\%) under $88-98$ ppb, but with no change in the chlorophyll $a / b$ ratio. A similar reduction was also observed in carotenoid (Car) content (15\%). All photosynthetic parameters of light and dark reactions decreased upon exposure to 67-101 ppb, that is, quantum efficiency of PSII photochemistry in the dark-adapted state 
TABLE 1 The $p$ value using resampling tests with 9,999 iterations to evaluate the between-group heterogeneity for growth, biomass, gas exchange, photosynthetic pigments, chlorophyll fluorescence, and antioxidant parameters of all woody species exposed to elevated $\left[\mathrm{O}_{3}\right]$ relative to control $\left[\mathrm{O}_{3}\right]$ in a weighted random-effects meta-analysis with categorical structure

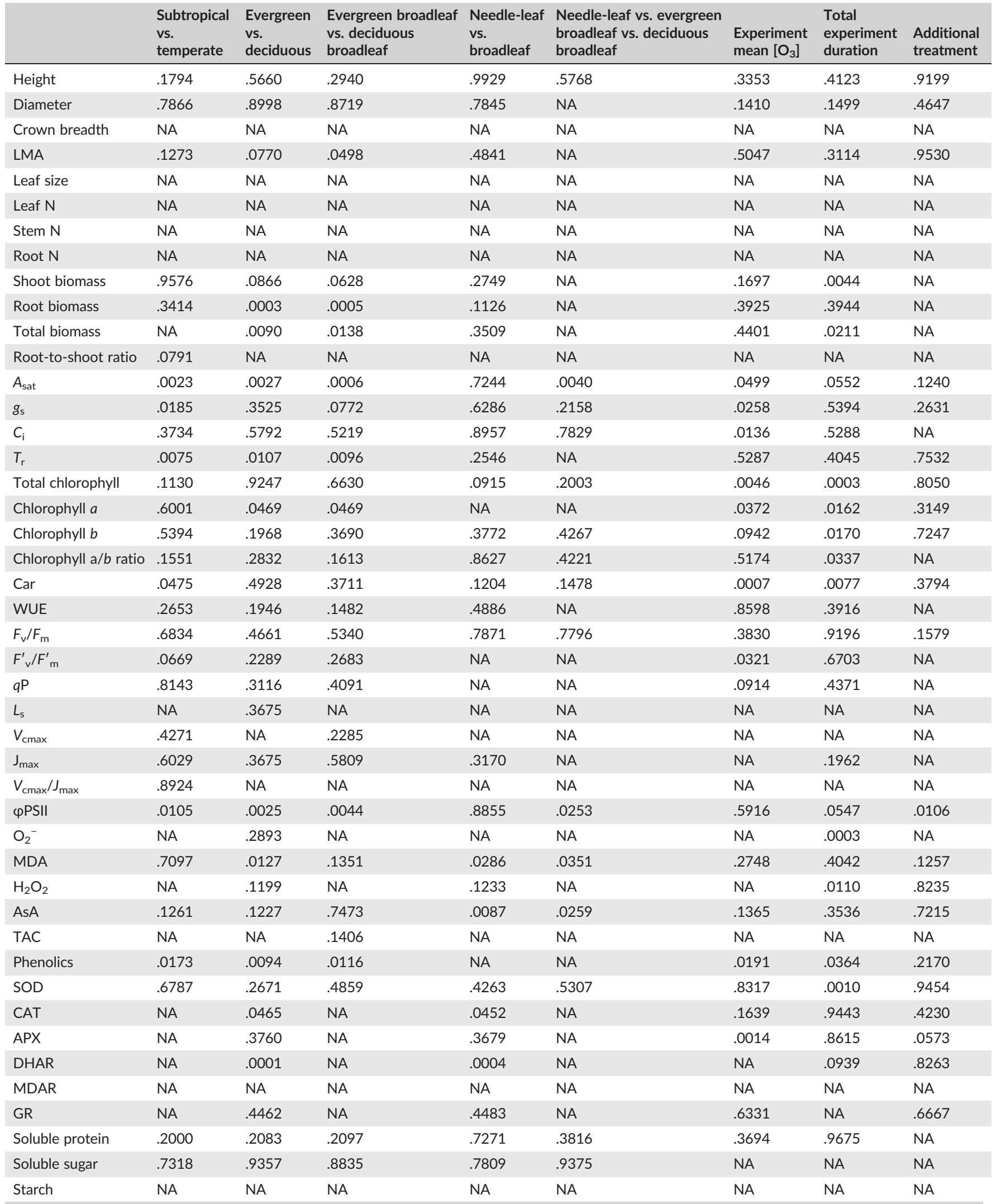

Note. The $p$ values $<0.05$ are considered significant. $\varphi$ PSII = effective quantum yield of photosystem II; APX = ascorbate peroxidase; $A$ sA = ascorbic acid; Car = carotenoid; $C A T$ = catalase; $\mathrm{DHAR}=$ dehydroascorbate reductase; $\mathrm{GR}=$ glutathione reductase; $\mathrm{LMA}=$ leaf mass per area; $\mathrm{MDA}=$ malondialdehyde; MDAR = monoascorbate reductase; $\mathrm{NA}=$ not available; $\mathrm{SOD}=$ superoxide dismutase activity; $\mathrm{TAC}=$ total antioxidant capacity; WUE = water-use efficiency. 
FIGURE 1 Effect of elevated $\left[\mathrm{O}_{3}\right]\left(\mathrm{eO}_{3}\right)$ on (a) growth, biomass, leaf characteristics, (b) gas exchange, photosynthetic pigments, chlorophyll fluorescence, and (c) antioxidant parameters of all tree species. Symbols represent the mean percent change at elevated $\left[\mathrm{O}_{3}\right]$ relative to control $\left[\mathrm{O}_{3}\right]$, and the bars show the $95 \%$ bootstrapped confidence intervals. Number of measurements and papers are shown in parentheses, whereas mean elevated $\left[\mathrm{O}_{3}\right]$ and control $\left[\mathrm{O}_{3}\right]$ (in brackets) are given along the $y$ axis. $\varphi P S I I=$ effective quantum yield of photosystem II; APX = ascorbate peroxidase; AsA = ascorbic acid; Car = carotenoid; CAT = catalase; DHAR = dehydroascorbate reductase; $\mathrm{GR}$ = glutathione reductase; LMA = leaf mass per area;

MDA = malondialdehyde;

MDAR = monoascorbate reductase;

SOD = superoxide dismutase activity;

$\mathrm{TAC}=$ total antioxidant capacity;

WUE = water-use efficiency

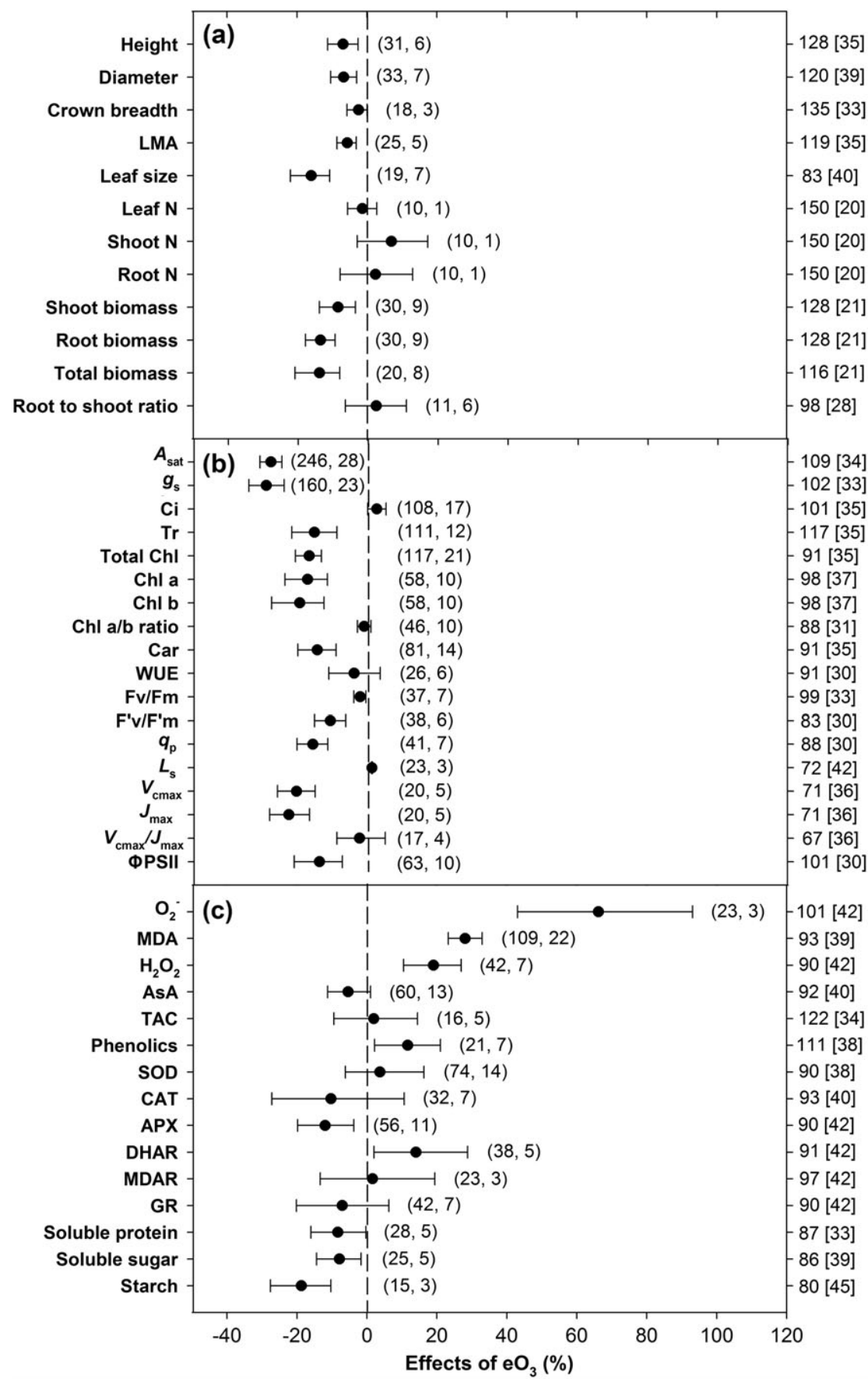

$\left(F_{v} / F_{m}, 2 \%\right)$, actual photochemical efficiency of PSII $\left(F_{v}^{\prime} / F_{m}^{\prime}, 11 \%\right)$, photochemical quenching coefficient ( $q \mathrm{P}, 16 \%)$, maximum rubiscocatalysed velocity of carboxylation $\left(V_{c m a x}, 21 \%\right)$, maximum rate of electron transport $\left(J_{\max }, 23 \%\right)$, and effective quantum yield of PSII photochemistry ( $\varphi$ PSII, 14\%). Also, soluble sugar (8\%) and starch (11\%) decreased following exposure to 80-86 ppb (Figure 1c).

Elevated $\left[\mathrm{O}_{3}\right]$ (90-101 ppb) significantly increased foliar superoxide radical $\left(\mathrm{O}_{2}{ }^{*}-\mathrm{-}\right)$, malondialdehyde (MDA), and hydrogen peroxide $\left(\mathrm{H}_{2} \mathrm{O}_{2}\right)$ content by $66 \%, 28 \%$, and $19 \%$, respectively (Figure 1c). Leaf non-enzymatic antioxidants such as total phenolics content significantly increased by $12 \%$, whereas enzymatic antioxidant activities decreased by $12 \%$ for ascorbate peroxidase (APX), but increased by $14 \%$ for dehydroascorbate reductase (DHAR; Figure 1c).

\section{3 | Differences between plant functional types or bioclimatic zones in the response to elevated $\left[\mathrm{O}_{3}\right]$}

Significant differences between NDL and broadleaf species were found in four variables, that is, MDA, ascorbic acid (AsA), catalase, and DHAR (Table 1 and Figure 2a). When plants were classified in $N D L, E B L$, and $D B L$ species, DBL showed much greater reduction in $A_{\text {sat }}$ and $\varphi P S I I$ in response to elevated $\left[\mathrm{O}_{3}\right]$ than the other two kinds of species (Figure 3a). Furthermore, given that the database included only five NDL species (i.e., Metasequoia glyptostroboides, Pinus armandii, Pinus elliottii, Pinus massoniana, and Pinus tabulaeformis), we compared the broadleaf response between EBL and DBL species. There were significant differences in root biomass, total biomass, $A_{\text {sat }}$, transpiration $\left(T_{\mathrm{r}}\right)$, chlorophyll $a, \varphi \mathrm{PSII}$, total phenolics content, and 


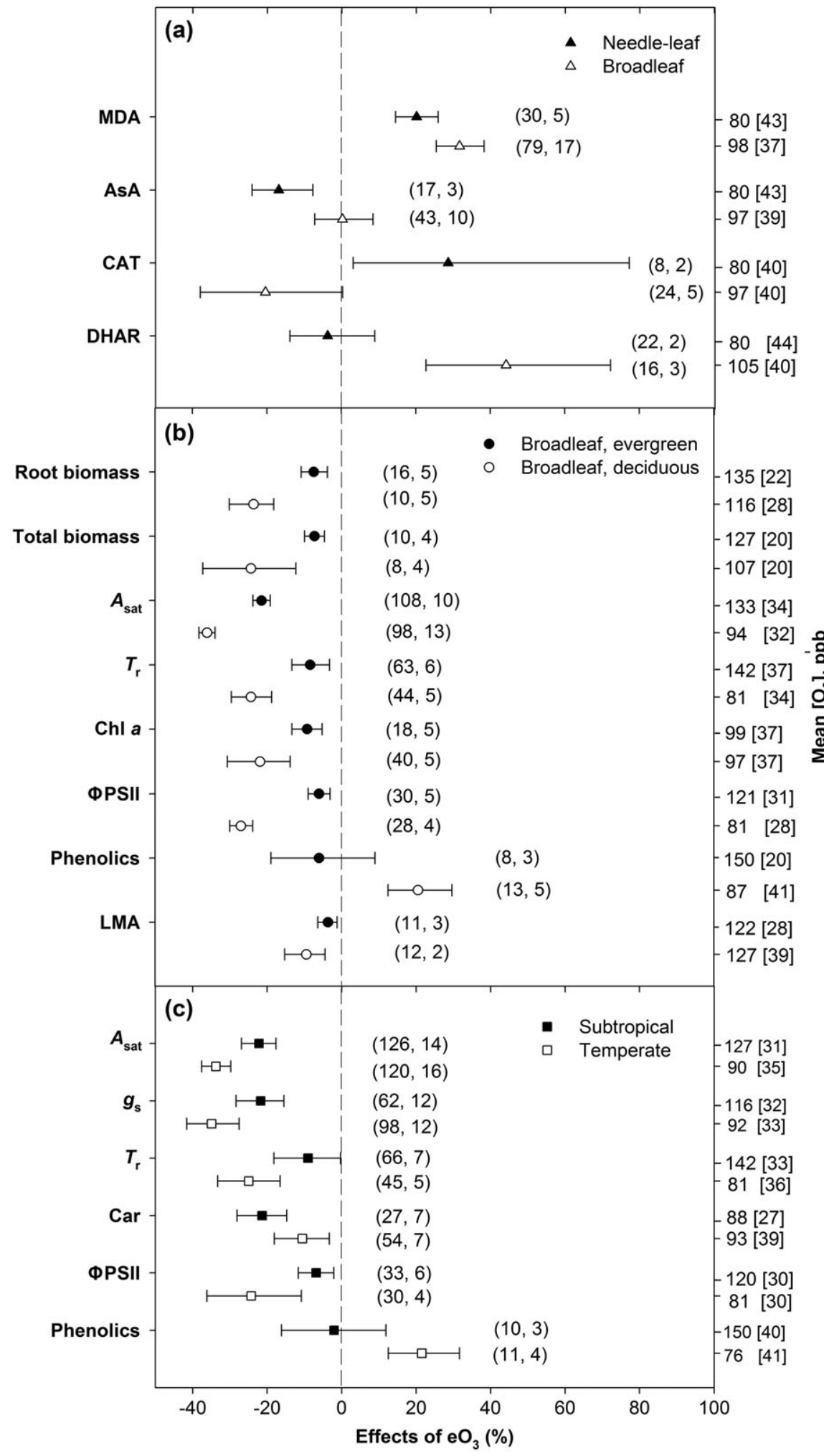

FIGURE 2 Effect of elevated $\left[\mathrm{O}_{3}\right]\left(\mathrm{eO}_{3}\right)$ on (a) needle-leaf $(\boldsymbol{\Lambda})$ and broadleaf $(\Delta)$, (b) broadleaf evergreen ( $(\mathbf{)}$ and broadleaf deciduous $(\mathrm{O})$, (c) subtropical ( $\square$ ) and temperate $(\square)$ woody species. Symbols represent the mean percent change at elevated $\left[\mathrm{O}_{3}\right]$ relative to control $\left[\mathrm{O}_{3}\right]$, and the bars show the $95 \%$ bootstrapped confidence intervals. Number of measurements and papers are shown in parentheses, whereas mean elevated $\left[\mathrm{O}_{3}\right]$ and control $\left[\mathrm{O}_{3}\right]$ (in brackets) are given along the $y$ axis. $\varphi$ PSII = effective quantum yield of photosystem II; AsA = ascorbic acid; Car = carotenoid; DHAR = dehydroascorbate reductase; $L M A$ = leaf mass per area; MDA = malondialdehyde; $\mathrm{TAC}=$ total antioxidant capacity
LMA (Table 1 and Figure $2 b$ ), indicating that EBL was less affected by elevated $\left[\mathrm{O}_{3}\right]$ relative to $\mathrm{DBL}$.

Furthermore, when species were compared on the basis of their bioclimatic zone, effects of elevated $\left[\mathrm{O}_{3}\right]$ on subtropical species were much lower than on temperate ones, concerning five significant variables, $A_{\mathrm{sat}}, g_{\mathrm{s}}, T_{\mathrm{r}}, \varphi \mathrm{PSII}$, and total phenolics, whereas Car was less affected in the temperate species than in the subtropical ones (Table 1 and Figure 2c). As most subtropical species were EBL, we tested evergreen versus deciduous species within the subtropical or temperate climate (Figure $3 b$ ). Data were sufficient for testing only $A_{\text {sat }}, g_{\mathrm{s}}$, and Car and confirmed a larger reduction in $A_{\text {sat }}$ in temperate $\mathrm{DBL}$ relative to temperate $\operatorname{EBL}(p=.0334)$, whereas no significant difference between subtropical $D B L$ and subtropical EBL was found in those three variables. Notably, however, the $g_{s}$ dataset of temperate evergreen species was based on only five observations from two papers, which may explain the large variation we observed (Figure 3b). 
FIGURE 3 Effect of elevated $\left[\mathrm{O}_{3}\right]\left(\mathrm{eO}_{3}\right)$ on (a) needle-leaf ( $\square$ ), evergreen broadleaf $(\square)$, and deciduous broadleaf $(\square$ ) woody species and (b) subtropical evergreen $(\nabla)$, subtropical deciduous $(\nabla)$, temperate evergreen ( $)$, and temperate deciduous ( () woody species. Symbols represent the mean percent change at elevated $\left[\mathrm{O}_{3}\right]$ relative to control $\left[\mathrm{O}_{3}\right]$, and the bars show the $95 \%$ bootstrapped confidence intervals. Number of measurements and papers are shown in parentheses, whereas mean elevated $\left[\mathrm{O}_{3}\right]$ and control $\left[\mathrm{O}_{3}\right]$ (in brackets) are given along the $y$ axis. $\varphi$ PSII = effective quantum yield of photosystem II; AsA = ascorbic acid; Car = carotenoid; $\mathrm{MDA}=$ malondialdehyde

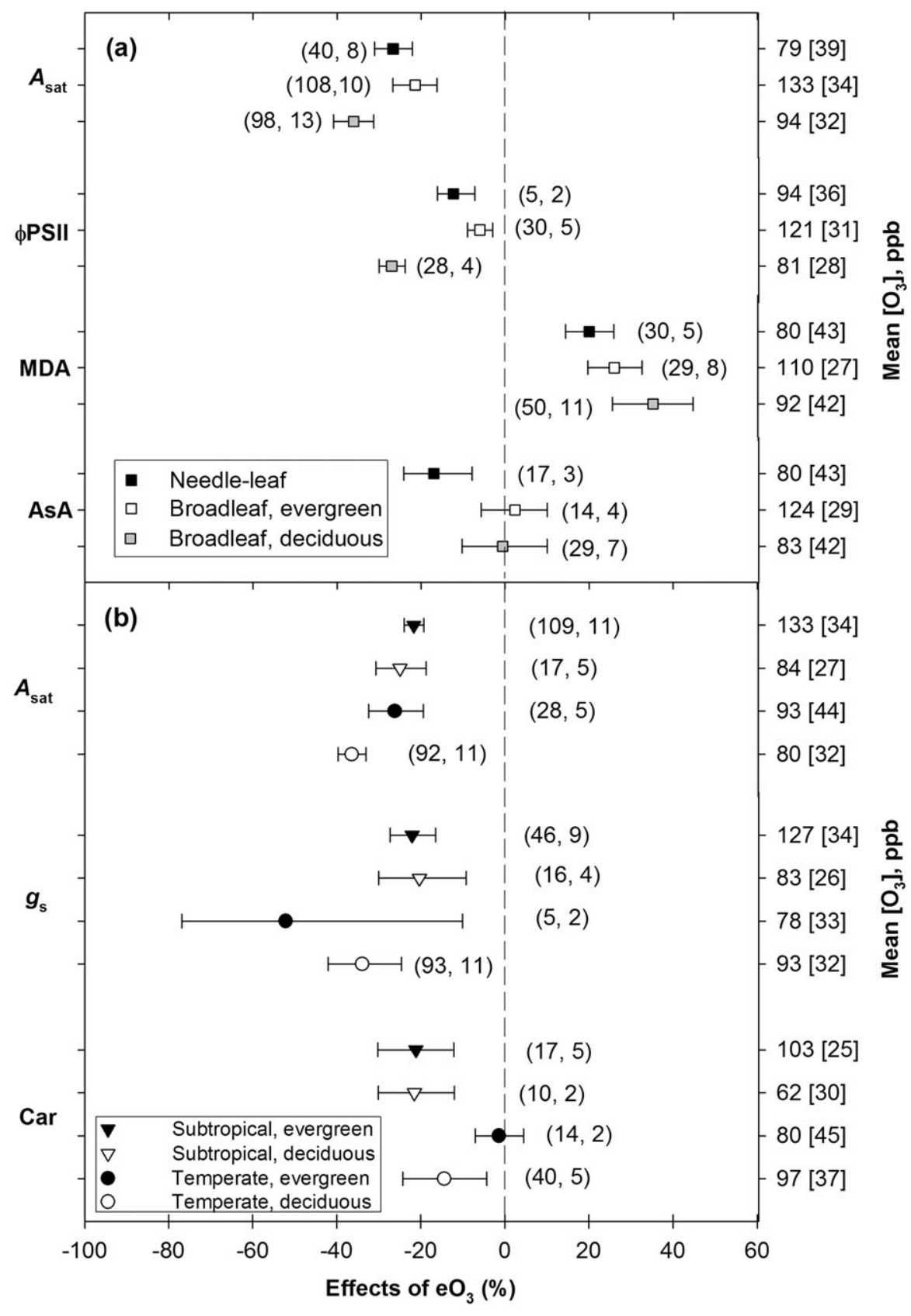

\subsection{Effects of $\mathrm{O}_{3}$ concentration and duration}

The detrimental effects of $\mathrm{O}_{3}$ on nine variables were significantly increased with increasing $\left[\mathrm{O}_{3}\right]$ (Table 1 and Figure 4). The decrease induced by elevated $\left[\mathrm{O}_{3}\right]$ in $A_{\mathrm{sat}}, g_{\mathrm{s}}$, total chlorophyll content, chlorophyll $a$, Car, $F^{\prime}{ }_{v} / F^{\prime}{ }_{m}, A P X$, and total phenolics content was significantly greater at high $\left[\mathrm{O}_{3}\right]$ than at lower $\left[\mathrm{O}_{3}\right]$ ranges, although this trend was not linear for some of the variables. An increasing trend with increasing $\left[\mathrm{O}_{3}\right]$ ranges was on the contrary found for intercellular $\mathrm{CO}_{2}$ concentrations $\left(C_{\mathrm{i}}\right)$.

There was a progressive decrease with increasing duration of exposure to elevated $\left[\mathrm{O}_{3}\right]$ in eight variables, whereas inverse trends were observed in four variables (Table 1 and Figure S2). Specifically, $A_{\text {sat }}$ (marginally significant, $p=.0552$, Table 1 ), total biomass, shoot biomass, chlorophyll content (total, chlorophyll $a$ and $b$ ), Car, and superoxide dismutase activity were significantly reduced in longer exposure duration ranges than in shorter exposure ones, with few exceptions. On the other hand, $\mathrm{O}_{2}{ }^{*}, \mathrm{H}_{2} \mathrm{O}_{2}$, and total phenolics content significantly increased with increasing exposure duration.

\section{4 | DISCUSSION}

\section{1 | Effects of ambient and elevated $\left[\mathrm{O}_{3}\right]$ on the productivity of Chinese woody species}

In our meta-analysis, the $\left[\mathrm{O}_{3}\right]$ ranged from 40 to $59 \mathrm{ppb}$, representing current ambient daytime $\left[\mathrm{O}_{3}\right]$ during plant growth in Asia and China (International Panel on Climate Change, 2013; Wan, Xia, Zhang, Wang, \& Wang, 2013), and significantly reduced leaf photosynthetic rates by $14 \%$ and photosynthetic pigment contents by $16 \%$ for chlorophyll $a+b$ and by $19 \%$ for Car (Figure 4). Also, modelling studies suggested 

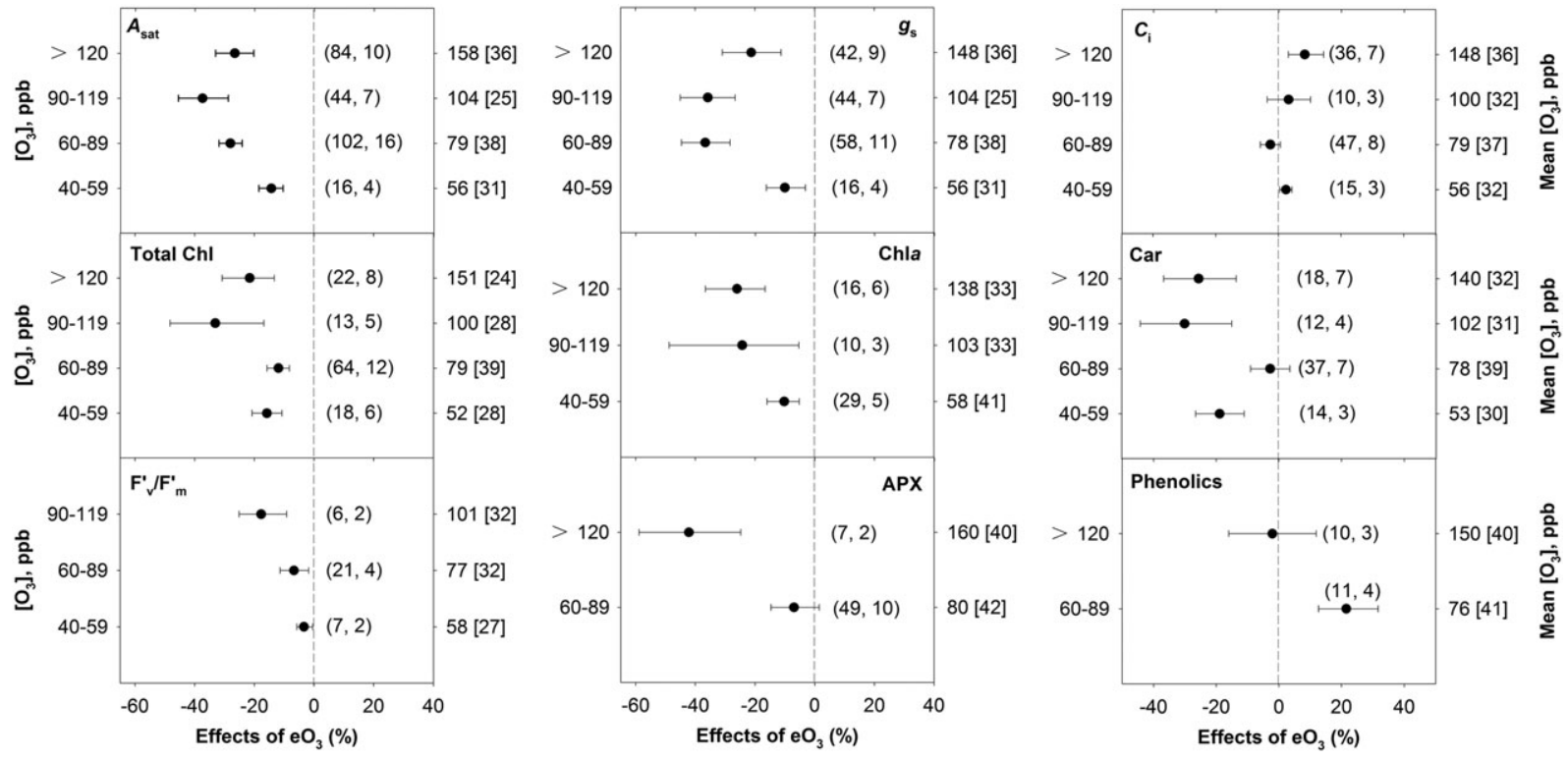

FIGURE 4 Effect of different concentrations of elevated $\mathrm{O}_{3}\left(\mathrm{eO}_{3} ;<40,40-59,60-89,90-119\right.$, and $\geq 120$ ppb). Symbols represent the mean percent change at elevated $\left[\mathrm{O}_{3}\right]$ relative to control $\left[\mathrm{O}_{3}\right]$, and the bars show the $95 \%$ bootstrapped confidence intervals. Number of measurements and papers are shown in parentheses, whereas mean elevated $\left[\mathrm{O}_{3}\right]$ and control $\left[\mathrm{O}_{3}\right]$ (in brackets) are given along the $y$ axis. APX = ascorbate peroxidase; Car = carotenoid

that northern forest carbon sink was depressed by current ambient $\left[\mathrm{O}_{3}\right](\sim 40 \mathrm{ppb})$ in the northern temperate zone relative to preindustrial times (Ehhalt et al., 2001; Sitch, Cox, Collins, \& Huntingford, 2007), as supported by meta-analyses of actual measurements showing decreased leaf photosynthetic rates (-11\%; Wittig et al., 2007) and biomass (-7\%; Wittig et al., 2009) of northern temperate forests. Moreover, 16 woody species displayed typical $\mathrm{O}_{3}$ symptoms in urban parks and mountain forest parks around Beijing (Feng et al., 2014). The quantitative and qualitative evidence suggested that ambient $\mathrm{O}_{3}$ is high enough to threaten the health of woody species in northern China. Unfortunately, inadequate sample size limited our understanding on the response of biomass to current $\left[\mathrm{O}_{3}\right]$ in China.

In comparison with the control $\left[\mathrm{O}_{3}\right]$ of $20-40 \mathrm{ppb}$, elevated $\left[\mathrm{O}_{3}\right]$, ranging from 83 to $150 \mathrm{ppb}$, caused significant reductions in biomass, stem height, stem diameter, LMA, and leaf size (Figure 1a), suggesting that the $\mathrm{CO}_{2}$ sequestration ability of Chinese woody species will be significantly reduced by future rising $\left[\mathrm{O}_{3}\right]$.

\subsection{Improved mechanistic understanding on $\mathrm{O}_{3}$ impacts on woody species}

The mechanism of $\mathrm{O}_{3}$ effects on plant functioning has been summarized in several review papers (e.g., Matyssek et al., 2002; Paoletti, 2006; Sharma, Jha, Dubey, \& Pessarakli, 2012; Tiwari, Grote, Chukina, \& Butler, 2016). Here, we improved this mechanistic understanding by quantifying the responses of key physiological and biochemical variables to $\mathrm{O}_{3}$ (Figure 1b,c). A major response to $\mathrm{O}_{3}$ exposure is stomatal closure, even though stomata may be slower to respond than in clean air (i.e., stomatal sluggishness; Paoletti \& Grulke, 2010). The reduction of steady-state $g_{s}(-29 \%)$, however, was tightly coupled with the reduction of $A_{\text {sat }}(-28 \%)$, suggesting that steady-state responses dominate on dynamic sluggishness. $A_{\text {sat }}$ may also be limited by non-stomatal factors, such as reductions in the maximum rate of carboxylation by Rubisco $\left(V_{\text {cmax }},-21 \%\right)$, the maximum electron transport capacity $\left(J_{\max },-23 \%\right)$, chlorophyll $(-17 \%)$, and Car $(-15 \%)$ contents. Similar results were also found in Wittig et al. (2009). A meta-analytical review of the effects of $\mathrm{O}_{3}$ on fluorescence parameters in woody species was provided here for the first time. Results indicated that leaf photosynthetic light reactions capacities were significantly decreased, as chlorophyll fluorescence parameters $\left(F_{v}{ }^{\prime} / F_{m}{ }^{\prime}-11 \%, \varphi P S I I\right.$ $-14 \%$, and $q \mathrm{P}-16 \%$ ) measured under steady light conditions were more sensitive to $\mathrm{O}_{3}$ than in the dark-adapted state $\left(F_{\mathrm{v}} / F_{\mathrm{m}},-2 \%\right)$. Changes in fluorescence under steady-state illumination may reflect a down-regulation process for adjusting the production of reducing power and chemical energy to a lower demand by the Calvin-Benson cycle (related with a lower Rubisco carboxylation activity). These physiological responses to elevated $\left[\mathrm{O}_{3}\right]$ result in less available carbon for growth. Furthermore, $\mathrm{O}_{3}$-induced reductions in nonstructural carbohydrates essential for growth such as soluble sugar $(-8 \%)$ and starch $(-11 \%)$ also indicated impaired photosynthetic process and decreased availability of photoassimilates for sink organs (Lemoine et al., 2013).

Antioxidant systems are important to detoxify $\mathrm{O}_{3}$ entering through the stomata into the leaves. The overall $\mathrm{O}_{3}$ effects on antioxidant systems of woody species were summarized for the first time by this meta-analysis. A significant increase in reactive oxygen species (ROS; 66\% in $\mathrm{O}_{2}{ }^{*-}$ and $19 \%$ in $\mathrm{H}_{2} \mathrm{O}_{2}$ ) and $28 \%$ in a lipid peroxidation marker, MDA, suggested that lipid molecules were degraded by an $\mathrm{O}_{3}$-induced overproduction of ROS (Calatayud, Iglesias, Talón, \& Barreno, 2003). However, the responses to oxidative stress demonstrated a large variability in our meta-analysis (Figure 1c). In the enzymatic antioxidant systems, no significant responses were detected in catalase, superoxide dismutase activity, monoascorbate reductase, and glutathione reductase, whereas significant effects were observed in DHAR (14\% increase) and APX (12\% decrease) at the $\left[\mathrm{O}_{3}\right]$ range 
of 90-97 ppb. The enzymes APX and DHAR use AsA and dehydroascorbate (DHA) as catalytic substrate, respectively, and are implicated into the glutathione-ascorbate cycle (Smirnoff, 1996). Reduction in APX and increase in DHAR could be explained by less AsA and more DHA in the leaf tissue due to an effective $\mathrm{O}_{3}$ detoxification. AsA/(AsA $\left.+D H A\right)$ plays a redox role allowing further reduction of $A s A$ to occur. Decreased AsA induces a reduction of APX catalytic functioning, whereas increased DHA stimulates an increase of DHAR (Sharma et al., 2012). From this study, elevated $\mathrm{O}_{3}$ (on average $92 \mathrm{ppb}$, ranging from 69 to $150 \mathrm{ppb})$ decreased AsA by $5 \%(95 \% \mathrm{Cl}:-11 \%$ to $1 \%$; Figure 1c) as expected, but the decrease was not significant. Such high AsA variability may depend not only on the diurnal variation in apoplast or symplast (Dizengremel, Jolivet, Tuzet, Ranieri, \& Le Thiec, 2013; Wang, Pang, Feng, Zhu, \& Kobayashi, 2015) but also on the magnitude of species-specific detoxification (Li et al., 2016; Sharma et al., 2012). When plants are exposed to $\mathrm{O}_{3}$ for a growing season or more, the antioxidant-buffering system in $\mathrm{O}_{3}$-sensitive species could be insufficient to offset the oxidative stress and finally lead to collapse across the metabolism-dependent process; but in $\mathrm{O}_{3}$-tolerant species, ROS-scavenging system are always active and could effectively diminish the propagation of oxidative signalling (Dizengremel et al., 2013). Considering the large amount of $\mathrm{O}_{3}$-tolerant evergreen species in the current database, most biochemical variables did not show significant effects by elevated $\left[\mathrm{O}_{3}\right]$, even at $122 \mathrm{ppb}$ (Table 1 and Figure 1).

\section{3 | Ozone effects depend on the plant functional group and bioclimatic zone}

In addition to the DBL and evergreen NDL species investigated by Wittig et al. (2007, 2009) (referred there as angiosperms and gymnosperms, respectively), several EBL species and one deciduous NDL species (Metasequoia glyptostroboides, Chinese endemic species) were included in this study. In Wittig et al. (2007), current ambient $\left[\mathrm{O}_{3}\right]$ significantly reduced $A_{\text {sat }}(-14 \%)$ and $g_{\mathrm{s}}(-16 \%)$ in DBL species (seven different genera) but not in NDL species (Picea and Pinus). However, projected future $\left[\mathrm{O}_{3}\right]$ in 2050 would be high enough to significantly impair both $A_{\text {sat }}\left(-17 \%\right.$ in NDL and $-20 \%$ in DBL) and $g_{s}$ $(-6 \%$ in NDL and $-12 \%$ in DBL) in both types of tree species (Wittig et al., 2007). In our study, elevated $\mathrm{O}_{3}$ also induced smaller effects on NDL than DBL, as indicated by a mean reduction in $A_{\text {sat }}$ of $27 \%$ for NDL and $36 \%$ for DBL, and a significantly lower lipid peroxidation in NDL (20\%) than DBL (35\%; Figure 3a), pointed to a higher sensitivity of $\mathrm{DBL}$ to $\mathrm{O}_{3}$ than NDL species.

However, the most tolerant to $\mathrm{O}_{3}$ among all groups was EBL, with reductions in $A_{\text {sat }}$ by $21 \%$ at very high $\left[\mathrm{O}_{3}\right]$ of $133 \mathrm{ppb}$ relative to $27 \%$ for NDL at $79 \mathrm{ppb}$ and $36 \%$ for DBL at $94 \mathrm{ppb}$ (Figures 2 and 3a). Effects of $\left[\mathrm{O}_{3}\right]$ on biomass can be compared only between $\mathrm{DBL}$ and EBL due to the limited data available for NDL. Significant differences were observed between both types of broadleaf species. Mean reduction in total biomass of $\mathrm{DBL}$ under elevated $\left[\mathrm{O}_{3}\right]$ (107 ppb) was $24 \%$, consistent with the $23 \%$ reported by Wittig et al. (2009) for the same functional type under lower $\left[\mathrm{O}_{3}\right]$ (74 ppb). In DBL, root biomass was much more affected $(-24 \%)$ than shoot biomass $(-5 \%)$, whereas the difference between root and shoot was small for EBL ( $-5 \%$ in shoot vs. $-7 \%$ in root). The dramatic decrease in carbon partitioning to roots of DBL has broad negative implications for both community composition and carbon sequestration. DBL species may be likely more vulnerable to environmental stress (e.g., nutrient, water, temperature, and oxidation) due to smaller root system and thus face the risk of loss in their own ecological niche under global change scenarios.

On the other hand, there is a discrepancy between effects of $\mathrm{O}_{3}$ on EBL at leaf and plant levels as reductions in $A_{\text {sat }}$ were $21 \%$ in contrast with only a $7 \%$ reduction in total biomass, which could be attributed to two facts. For DBL, a common response to elevated $\left[\mathrm{O}_{3}\right]$ is accelerated leaf senescence processes, which may significantly decrease plant foliar area, although plant resources are diverted to promote development of new leaves (Pell, Brendley, \& Sinn, 1996). However, the construction cost of EBL leaves is higher than in DBL, and these leaves last longer leading to lower amortized costs per leaf construction (Givnish, 2002). Therefore, a possible explanation of the lower impacts of $\mathrm{O}_{3}$ on biomass in EBL may be that leaf area is better preserved in EBL than in DBL. Another mechanism protecting EBL from $\mathrm{O}_{3}$ stress is their higher antioxidant capacity per area, related to their higher LMA. Li et al. (2016) investigated the responses of 29 Chinese woody species to elevated $\left[\mathrm{O}_{3}\right]$ (both $\mathrm{DBL}$ and $\mathrm{EBL}$, data included in the present meta-analysis) and found that $\mathrm{O}_{3}$ sensitivity was linked to both LMA and leaf area-based antioxidant levels, but not to variation in leaf mass-based antioxidant levels or stomatal conductance. Comparative studies in DBL and EBL from the Mediterranean biome also support a higher $\mathrm{O}_{3}$ tolerance in EBL than DBL under non-water-limiting conditions due to constitutive differences in LMA and other leaf traits (Calatayud et al., 2010; Calatayud et al., 2011). In the recent publication (Feng et al., 2017), biomass reductions were more strongly related to stomatal flux per unit leaf mass than to stomatal flux per unit leaf area. Relationships for broadleaf and needleleaf species converged when using the LMA-based index. So the stomatal $\mathrm{O}_{3}$ flux per mass-biomass reduction after the LMA conversion is very useful to model the large-scale effects of $\mathrm{O}_{3}$ on woody species productivity.

A complementary analysis was carried out to compare effects of $\mathrm{O}_{3}$ on plants from temperate and subtropical biomes. It was estimated that ambient $\left[\mathrm{O}_{3}\right]$ induced a smaller loss of net carbon storage in (sub) tropical EBL (-0.1 Tg C year $\left.{ }^{-1}\right)$ and DBL $\left(-0.1 \mathrm{Tg}^{\mathrm{C}}\right.$ year $\left.^{-1}\right)$ than that in temperate EBL (-0.7 $\mathrm{Tg} \mathrm{C}$ year $^{-1}$ ) and DBL (-6.7 $\mathrm{Tg} \mathrm{C}$ year ${ }^{-1}$ ) during the period 1961 and 2005 across China's forests (Ren et al., 2011), suggesting that the temperate $\mathrm{DBL}$ was more sensitive to $\mathrm{O}_{3}$ than other types of forest. This is consistent with our results that physiological and biochemical parameters are more affected by $\mathrm{O}_{3}$ in temperate $\mathrm{DBL}$ species than in subtropical ones (Figures $2 \mathrm{c}$ and $3 \mathrm{~b}$ ). Additionally, a high diversity of functional plant types was recorded in our database, including several evergreen bamboo species, evergreen and deciduous conifers, and DBL woody species. Results pointed towards a high diversity of responses in subtropical species partly in relation with their dominant functional type. Therefore, responses to elevated $\left[\mathrm{O}_{3}\right]$ in the future are expected to be rather heterogeneous in China. These differences in sensitivity are relevant in terms of setting critical levels and for risk assessment in these areas. 


\subsection{Implications for carbon and hydrological cycles}

Sitch et al. (2007) highlighted large potential impacts of future $\left[\mathrm{O}_{3}\right]$ on the ability of many ecosystems to sequester carbon, with large impacts expected in tropical areas of South America, Africa, and Asia in biomes dominated by EBL trees. However, only two types of plant sensitivity (low-based on temperate oaks and high-based on temperate beech and birch) were considered in the model for estimating an upper and a lower range in expected gross primary production changes for the world (Sitch et al., 2007). Our results clearly indicated a much lower impact on carbon uptake in large areas dominated by subtropical and tropical EBL species. Moreover, this EBL functional type is also dominant in other parts of the world as in the Mediterranean area, consistently showing a lower $\mathrm{O}_{3}$ sensitivity than $\mathrm{DBL}$ (Calatayud et al., 2010; Calatayud et al., 2011; Paoletti, 2006). EBL is also an important component of sclerophyll woodlands and temperate forests in the southern hemisphere (Givnish, 2002). The significance of EBL for global modelling estimates of $\mathrm{O}_{3}$ impacts on the carbon-sink capacity of vegetation suggests that the modelling results from Sitch et al. (2007) might overestimate the negative effects of $\mathrm{O}_{3}$ on carbon sequestration of forests dominated by EBL.

All gas exchange measurements in the present meta-analysis were carried out at steady state by LI-COR gas analyzers and showed that $g_{\mathrm{s}}$ reductions were much higher in Chinese woody plants $(-29 \%)$ with high values both for evergreen (-22\%) and deciduous broadleaves $(-33 \%)$ than those in European and American species (Wittig et al., 2007), suggesting that rising $\mathrm{O}_{3}$ may have important impacts on the hydrological cycle at regional scale. Current experimental results support the modelling estimate that $\mathrm{O}_{3}$ is expected to increase river run-off and freshwater availability due to reduced water use via transpiration from vegetation (Sitch, Arnold, Collins, \& Jones, 2012). However, exposure to high $\mathrm{O}_{3}$ concentration may induce stomatal sluggishness and thus reduce the stomatal control of leaf transpiration; therefore, more water emitted to the atmosphere (Uddling, Teclaw, Pregitzer, \& Ellsworth, 2009; Hoshika et al. 2015). At regional scale, increases in evapotranspiration and associated streamflow reductions in response to ambient $\mathrm{O}_{3}$ exposure are expected to episodically increase the frequency and severity of drought and affect flow-dependent aquatic biota in forested watersheds (Sun et al., 2012). Therefore, it is vital to investigate the effects of elevated $\mathrm{O}_{3}$ on water use of different plant functional types.

\section{5 | CONCLUSIONS}

Our study provided a quantitative understanding of how present and future $\left[\mathrm{O}_{3}\right]$ impair $\mathrm{CO}_{2}$ assimilation through a combination of biochemical and non-biochemical limitations, such as photosynthetic pigments and the photochemical efficiency of photosynthetic processes in Chinese woody species. Effects were more severe in deciduous broadleaf species and temperate climates than in evergreen species and subtropical climates. However, the future extent and severity of these effects are difficult to be predicted in the context of multiple-stressor climate change. Raising $\left[\mathrm{CO}_{2}\right]$ and drought have been suggested to alleviate $\mathrm{O}_{3}$ deleterious effects, partly by promoting stomatal closure and reducing $\mathrm{O}_{3}$ uptake (Ainsworth, Yendrek, Sitch,
Collins, \& Emberson, 2012). More combined experiments on the impacts of $\mathrm{O}_{3}$ and co-occurring stressors on woody species are warranted, as the present knowledge is insufficient for being included in this meta-analysis.

\section{ACKNOWLEDGMENTS}

This study was funded by Key Research Program of Frontier Sciences, CAS (QYZDB-SSW-DQC019), the Hundred Talents Program, Chinese Academy of Sciences, Chinese Academy of Sciences President's International Fellowship Initiative (PIFI) for Senior Scientists (2013T2Z0009; 2016VBA057), National Natural Science Foundation of China (31500396), and CNR-CAS bilateral agreement 2017-2019 "Ozone impacts on plant ecosystems in China and Italy." This paper is part of the work carried out within the IUFRO Task Force on Climate Change and Forest Health.

\section{ORCID}

Zhaozhong Feng (10) http://orcid.org/0000-0002-9775-5113

Elena Paoletti (1) http://orcid.org/0000-0001-5324-7769

\section{REFERENCES}

Ainsworth, E. A., Davey, P. A., Bernacchi, C. J., Dermody, O. C., Heaton, E. A., Moore, D. J., ..., Long, S. P. (2002) A meta-analysis of elevated $\left[\mathrm{CO}_{2}\right]$ effects on soybean (Glycine max) physiology, growth and yield. Global Change Biology, 8, 695-709.

Ainsworth, E. A., Yendrek, C. R., Sitch, S., Collins, W. J., \& Emberson, L. D. (2012). The effects of tropospheric ozone on net primary productivity and implications for climate change. Annual Review of Plant Biology, 63, 637-661.

Allen, R. J., Sherwood, S. C., Norris, J. R., \& Zender, C. S. (2012). Recent northern hemisphere tropical expansion primarily driven by black carbon and tropospheric ozone. Nature, 485, 350-354.

Calatayud, A., Iglesias, D. J., Talón, M., \& Barreno, E. (2003). Effects of 2-month ozone exposure in spinach leaves on photosynthesis, antioxidant systems and lipid peroxidation. Plant Physiology and Biochemistry, 41, 839-845.

Calatayud, V., Cervero, J., Calvo, E., Garcia-Breijo, F. J., Reig-Arminana, J., \& Sanz, M. J. (2011). Responses of evergreen and deciduous Quercus species to enhanced ozone levels. Environmental Pollution, 159, 55-63.

Calatayud, V., Marco, F., Cervero, J., Sanchez-Pena, G., \& Sanz, M. J. (2010). Contrasting ozone sensitivity in related evergreen and deciduous shrubs. Environmental Pollution, 158, 3580-3587.

Castagna, A., \& Ranieri, A. (2009). Detoxification and repair process of ozone imjury: From $\mathrm{O}_{3}$ uptake to gene expression adjustment. Environmental Pollution, 157, 1461-1469.

Chen, W., Tang, H. Z., \& Zhao, H. M. (2015). Diurnal, weekly and monthly spatial variations of air pollutants and air quality of Beijing. Atmospheric Environment, 119, 21-34.

Curtis, P. S. \& Wang, X. (1998) A meta-analysis of elevated CO2 effects on woody plant mass, form, and physiology. Oecologia, 113, 299-313.

Dizengremel, P., Jolivet, Y., Tuzet, A., Ranieri, A., \& Le Thiec, D. (2013). Integrative leaf-level ozone phytotoxic ozone dose assessment for forest risk modeling. In R. Matyssek, N. Clarke, P. Cudlin, T. N. Mikkelsen, J. P. Tuovinen, G. Wieser, \& E. Paoletti (Eds.), Climate change, air pollution and global challenges (Developments in Environmental Sciences 13) (pp. 267-288). Netherlands: Elsevier.

Duan, H. C., Yan, C. Z., Tsunekawa, A., Song, X., Li, S., \& Xie, J. L. (2011). Assessing vegetation dynamics in the Three-North Shelter Forest region of China using AVHRR NDVI data. Environmental Earth Sciences, 64, 1011-1020. 
Ehhalt, D., Prather, M., Dentener, F., Derwent, R., Dlugokencky, E., Holland, E. A., ... Wang, M. (2001). Atmospheric chemistry and greenhouse gases. In J. J. Maccarthy, O. F. Canziani, \& N. A. Leary (Eds.), Climate change 2001: Impacts, adaptation and vulnerability (pp. 239-287). Cambridge, UK/New York, NY, USA: Cambridge University Press.

Fang, J. Y., Guo, Z. D., Hu, H. F., Kato, T., Muraoka, H., \& Son, Y. (2014). Forest biomass carbon sinks in East Asia, with special reference to the relative contributions of forest expansion and forest growth. Global Change Biology, 20, 2019-2030.

Fang, J. Y., Shen, Z. H., Tang, Z. Y., Wang, X. P., Wang, Z. H., Feng, J. M., ... Zheng, C. Y. (2012). Forest community survey and the structural characteristics of forests in China. Ecography, 35, 1059-1071.

Feng, Z. Z., Büker, P., Pleijel, H., Emberson, L., Karlsson, P. E., \& Uddling, J. (2017). A unifying explanation for variation in ozone sensitivity among woody plants. Global Change Biology. https://doi.org/10.1111/ gcb.13824

Feng, Z. Z., Kobayashi, K. \& Ainsworth, E. A. (2008). Impact of elevated ozone concentration on growth, physiology, and yield of wheat (Triticum aestivum L.): A meta-analysis. Global Change Biology, 14, 2696-2708.

Feng Z.Z. \& Li P. (2017) Effects of ozone on Chinese trees. In Air pollution impacts on plants in east Asia (ed T. Izuta), Springer, Nishi-Kanda, Chiyoda-ku, Tokyo, Japan.

Feng, Z. Z., Niu, J. F., Zhang, W. W., Wang, X. K., Yao, F. F., \& Tian, Y. (2011). Effects of ozone exposure on sub-tropical evergreen Cinnamomum camphora seedlings grown in different nitrogen loads. Trees-Structure and Function, 25, 617-625.

Feng, Z. Z., Paoletti, E., Bytnerowicz, A., \& Harmens, H. (2015). Ozone and plants. Environmental Pollution, 202, 215-216.

Feng, Z. Z., Sun, J. S., Wan, W. X., Hu, E. Z., \& Calatayud, V. (2014). Evidence of widespread ozone-induced visible injury on plants in Beijing, China. Environmental Pollution, 193, 296-301.

Forster, P., Ramaswamy, V., Artaxo, P., Berbtsen, T., Betts, R., Fahey, D. W., ... Van Dorland, R. (2007). Changes in atmospheric constituents and in radiative forcing. In S. Solomon, D. Qin, M. Manning, Z. Chen, M. Marquis, K. B. Averyt, et al. (Eds.), Climate change 2007: The physical science basis. Contribution of Working Group I to the Fourth Assessment Report of the Intergovernmental Panel on Climate Change (pp. 129-234). Cambridge, UK/New York, NY, USA: Cambridge University Press.

Gao, F., Catalayud, V., García-Breijo, F., Reig-Armiñana, J., \& Feng, Z. Z. (2016). Effects of elevated ozone on physiological, anatomical and ultrastructural characteristics of four common urban tree species in China. Ecological Indicators, 67, 367-379.

Givnish, T. J. (2002). Adaptive significance of evergreen vs. deciduous leaves: Solving the triple paradox. Silva Fennica, 36, 703-743.

He, X. Y., Fu, S. L., Chen, W., Zhao, T. H., Xu, S., \& Tuba, Z. (2007). Changes in effects of ozone exposure on growth, photosynthesis, and respiration of Ginkgo biloba in Shenyang urban area. Photosynthetica, 45, 555-561.

He, X. Y., Ruan, Y. N., Chen, W., \& Lu, T. (2006). Responses of the anti-oxidative system in leaves of Ginkgo biloba to elevated ozone concentration in an urban area. Botanical Studies, 47, 409-416.

Hoshika, Y., Katata, G., Deushi, M., Watanabe, M., Koike, T. \& Paoletti, E. (2015). Ozone-induced stomatal sluggishness changes carbon and water balance of temperate deciduous forests. Scientific Reports, 5, https://doi.org/10.1038/srep09871

International Panel on Climate Change (2013) Fifth Assessment Report Intergovernmental Panel on Climate Change. http://www.ipcc.ch/ report/ar5/index.shtml.

International Panel on Climate Change (2014). Summary for policymakers. In C. B. Field, V. R. Barros, D. J. Dokken, K. J. Mach, M. D. Mastrandrea, T. E. Bilir, et al. (Eds.), Climate change 2014: Impacts, adaptation, and vulnerability. Part A: Global and sectoral aspects. Contribution of Working Group II to the Fifth Assessment Report of the Intergovernmental Panel on
Climate Change (pp. 1-32). Cambridge, UK and New York, NY, USA: Cambridge University Press.

Lemoine, R., La Camera, S., Atanassova, R., Dédaldéchamp, F., Allario, T., Pourtau, N., ... Durand, M. (2013). Source-to-sink transport of sugar and regulation by environmental factors. Frontiers in Plant Science, 4. https://doi.org/10.3389/fpls.2013.00272

Li, P., Calatayud, V., Gao, F., Uddling, J., \& Feng, Z. Z. (2016). Differences in ozone sensitivity among woody species are related to leaf morphology and antioxidant levels. Tree Physiology, 36, 1105-1116.

Liu, J., \& Diamond, J. (2005). China's environment in a globalizing world. Nature, 435, 1179-1186.

Lü, Y. H., Fu, B. J., Wei, W., Yu, X. B., \& Sun, R. H. (2011). Major ecosystems in China: Dynamics and challenges for sustainable management. Environmental Management, 48, 13-27.

Matyssek, R., Schnyder, H., Elstner, E. F., Munch, J. C., Pretzsch, H., \& Sandermann, H. (2002). Growth and parasite defence in plants; the balance between resource sequestration and retention: In lieu of a guest editorial. Plant Biology, 4, 133-136.

Myers, N., Mittermeier, R. A., Mittermeier, C. G., Fonseca, G. A. B. D., \& Kent, J. (2000). Biodiversity hotspots for conservation priorities. Nature, 403, 853-858.

Paoletti, E. (2006). Impact of ozone on Mediterranean forests: A review. Environmental Pollution, 144, 463-474.

Paoletti, E., \& Grulke, N. E. (2010). Ozone exposure and stomatal sluggishness in different plant physiognomic classes. Environmental Pollution, 158, 2664-2671.

Paoletti, E., \& Manning, W. J. (2007). Toward a biologically significant and usable standard for ozone that will also protect plants. Environmental Pollution, 150, 85-95.

Paoletti, E., Ranieri, A., \& Lauteri, M. (2008). Moving toward effective ozone flux assessment. Environmental Pollution, 156, 16-19.

Pell, E. J., Brendley, B. W., \& Sinn, J. P. (1996). Ozone-induced accelerated foliar senescence: Implications for toxicity and compensation. In J. Hom, R. Birdsey, \& K. O'Brian (Eds.), Proceedings, 1995 meeting of the Northern Global Change Program (Gen. Tech. Rep. NE-214) (pp. 13-19). Radnor, PA: U.S. Department of Agriculture, Forest Service, Northeastern Forest Experiment Station.

Ren, G., Young, S. S., Wang, L., Wang, W., Long, Y., Wu, R., ... Yu, D. W. (2015). Effectiveness of China's National Forest Protection Program and nature reserves. Conservation Biology, 29, 1368-1377.

Ren, W., Tian, H. Q., Tao, B., Chappelka, A., Sun, G., Lu, C. Q., ... Xu, X. F. (2011). Impacts of tropospheric ozone and climate change on net primary productivity and net carbon exchange of China's forest ecosystems. Global Ecology and Biogeography, 20, 391-406.

Rosenberg, M. S., Adams, D. C. \& Gurevitch, J. (2000). Metawin: Statistical Software for Meta-Analysis, Version 2.1. Sinauer Associates, Inc, Sunderland, MA, USA.

Sharma, P., Jha, A. B., Dubey, R. S., \& Pessarakli, M. (2012). Reactive oxygen species, oxidative damage, and antioxidative defense mechanism in plants under stressful conditions. Journal of Botany. https://doi.org/ 10.1155/2012/217037

Sitch, S., Arnold, S., Collins, B., \& Jones, C. (2012). Ozone impacts on carbon storage in terrestrial ecosystems: A global perspective. In H. Harmens, \& G. Mills (Eds.), Ozone pollution: Impacts on carbon sequestration in Europe (pp. 51-67). Bangor, UK: Centre for Ecology and Hydrology.

Sitch, S., Cox, P. M., Collins, W. J., \& Huntingford, C. (2007). Indirect radiative forcing of climate change through ozone effects on the land-carbon sink. Nature, 448, 791-794.

Smirnoff, N. (1996). Botanical briefing: The function and metabolism of ascorbic acid in plants. Annals of Botany, 78, 661-669.

Sun, G. E., McLaughlin, S. B., Porter, J. H., Uddling, J., Mulholland, P. J., Adams, M. B., \& Pederson, N. (2012). Interactive influences of ozone and climate on streamflow of forested watersheds. Global Change Biology, 18, 3395-3409. 
The Royal Society (2008). Ground-level ozone in the $21^{\text {st }}$ century: Future trends, impacts and policy implications. Science Policy Report 15/08. The Royal Society, London.

Tiwari, S., Grote, R., Chukina, G., \& Butler, T. (2016). Ozone damage, detoxification and the role of isoprenoid-New impetus for integrated models. Functional Plant Biology, 43, 324-336.

Uddling, J., Teclaw, R. M., Pregitzer, K. S., \& Ellsworth, D. S. (2009). Leaf and canopy conductance in aspen and aspen-birch forests under free-air enrichment of carbon dioxide and ozone. Tree Physiology, 29, 1367-1380.

Van der, A. R. J., Eskes, H. J., Boersma, K. F., van Noije, T. P. C., van Roozendael, M., de Smedt, I., ... Meijer, E. W. (2008). Trends, seasonal variability and dominant $\mathrm{NO}_{\mathrm{x}}$ source derived from a ten year record of $\mathrm{NO}_{2}$ measured from space. Journal of Geophysical Research: Atmosphere, 113. D04302

van der Sleen, P., Groenendijk, P., Vlam, M., Anten, N. P. R., Boom, A., Bongers, F., ... Zuidema, P. A. (2015). No growth stimulation of tropical trees by 150 years of $\mathrm{CO}_{2}$ fertilization but water-use efficiency increased. Nature Geoscience, 8, 24-28.

Verstraeten, W. W., Neu, J. L., Williams, J. E., Bowman, K. W., Worden, J. R., \& Boersma, K. F. (2015). Rapid increases in tropospheric ozone production and export from China. Nature Geoscience, 8, 690-695.

Wan, W. X., Xia, Y. J., Zhang, H. X., Wang, J., \& Wang, X. K. (2013). The ambient ozone pollution and foliar injury of the sensitive woody plants in Beijing exurban region. Acta Ecologica Sinica, 33, 1098-1105. (in Chinese)

Wang, L., Pang, J., Feng, Z. Z., Zhu, J. G., \& Kobayashi, K. (2015). Diurnal variation of apoplastic ascorbate in winter wheat leaves in relation to ozone detoxification. Environmental Pollution, 207, 413-419.

Wang, X. K., Manning, W., Feng, Z. W., \& Zhu, Y. G. (2007). Ground-level ozone in China: Distribution and effects on crop yields. Environmental Pollution, 147, 394-400.

Wittig, V. E., Ainsworth, E. A., \& Long, S. P. (2007). To what extent do current and projected increases in surface ozone affect photosynthesis and stomatal conductance of trees? A meta-analytic review of the last 3 decades of experiments. Plant Cell and Environment, 30, 1150-1162.

Wittig, V. E., Ainsworth, E. A., Naidu, S. L., Karnosky, D. F., \& Long, S. P. (2009). Quantifying the impact of current and future tropospheric ozone on tree biomass, growth, physiology and biochemistry: A quantitative meta-analysis. Global Change Biology, 15, 396-424.

Wu, Z. Y., Sun, H., Zhou, Z. K., Li, D. Z. \& Peng, H. (2010). Floristics of seed plants from China. Beijing Science Press. (in Chinese)

Xu, S., He, X. Y., Chen, W., Su, D. Y., \& Huang, Y. Q. (2014). Elevated $\mathrm{CO}_{2}$ ameliorated the adverse effect of elevated $\mathrm{O}_{3}$ in previous-year and current-year needles of Pinus tabulaeformis in urban area. Bulletin of Environmental Contamination and Toxicology, 92, 733-737.

Yan, K., Chen, W., He, X. Y., Zhang, G. Y., Xu, S., \& Wang, L. L. (2010). Responses of photosynthesis, lipid peroxidation and antioxidant system in leaves of Quercus mongolica to elevated $\mathrm{O}_{3}$. Environmental and Experimental Botany, 69, 198-204.

Zhang, W. W., Feng, Z. Z., Wang, X. K., \& Niu, J. F. (2012). Responses of native broadleaved woody species to elevated ozone in subtropical China. Environmental Pollution, 163, 149-157.

\section{SUPPORTING INFORMATION}

Additional Supporting Information may be found online in the supporting information tab for this article.

How to cite this article: Li P, Feng Z, Catalayud V, Yuan X, Xu $\mathrm{Y}$, Paoletti E. A meta-analysis on growth, physiological, and biochemical responses of woody species to ground-level ozone highlights the role of plant functional types. Plant Cell Environ. 2017;40:2369-2380. https://doi.org/10.1111/pce.13043 